\title{
„Ложка страху в діжці мотороші", або кілька слів про найновішу українську антологію жахів
}

\author{
Вбивство на вулиці... . Збірка оповідань, укл. і передм. \\ А. Гаврильченко, Вінниця: Дім Химер, 2019, 260 с.
}

\begin{abstract}
AвSTRACT: Horniatko-Szumiłowicz Anna, „Lozhka strakhu v dizhtsi motoroshi”, abo kil'ka sliv pro naynovishu ukrayinsku antologiyu zhakhiv ("A Spoonful of Fear in an Artesa of Macabre" or a Few Words About the Newest of Ukrainian Horror Anthologies) "Poznańskie Studia Slawistyczne" 17. Poznań 2019. Publishing House of the Poznań Society for the Advancement of the Arts and Sciences, Adam Mickiewicz University, pp. 365-377. ISSN 2084-3011.
\end{abstract}

The release of the newest anthology of macabre short stories "Вбивство на вулиці..." (2019) affirmed the superb state of homebred horror literature. The aim of this paper is to analyze and evaluate the seventeen stories that form the aforementioned anthology. Analysis of the anthology has proven that despite a few creative shortcomings of young litterateurs, the "Вбивство на вулиці..." anthology maintains a high level of quality and deserves to be called a bestseller.

KEYwORDS: anthology; horror story; suspense; literary tradition; Ukrainian literature

Коли у 2000-му році київське видавництво „Асоціація підтримки української популярної літератури” опублікувало у червоній палітурці і великому форматі 800-сторінкову Антологію украӥнського жаху, читач достеменно переконався у багатовіковій традиції української літературної готики ${ }^{1}$. Упорядник книги, любитель і збирач вітчизняної

${ }^{1}$ Раніше 3'явилась тільки антологія Огненний змій (Винничук, 1990), в якій відомий письменник і упорядник книги Юрій Винничук помістив класичні зразки українського демонологічного оповідання, зокрема доби романтизму. На порталі „Толока” рекомендують Огненного змія, підкреслюючи, що „з цієї книжки читач вперше зможе переконатися, якої художньої висоти досягла українська романтична фантастика — це 
літератури жахів, Василь Пахаренко помістив у ній найяскравіші зразки малої готичної прози, починаючи від „страшного фольклору”, крізь давню українську літературу, iї класичні періоди, аж до зразків 80-х і 90-х років ХХ ст.

Доречно пригадати, що в радянський період українська література „з темних джерел життя” (М. Могилянський)² замовчувалась, а то й цілком заперечувалась: мовляв, не може бути в письменстві соціалістичного реалізму зневірницьких мотивів, авторів, які вірили б у потойбіччя, плекали б фольклорні традиції, черпали б натхнення 3 літературної спадщини прихильників „буржуазного націоналізму”, породжених ідеологами „гнилого Заходу”.

Після сенсаційної появи Антологї українського жаху на українському вільному від цензури з часів проголошення незалежної України (1991) видавничому ринку почали з'являтися друком нові антології українського жаху (Нічний гість, 2001; Чорт зна щзо, 2004; Потойбічне. Украӥнська тотична проза ХХ ст., 2005; Огняний змій. Украӥнська готична проза XIX cm., 2006; Антологія української тотичної прози. У двох томах, 2014 та ін.), на цей раз, головно, за сприянням Юрія Винничука (див., напр. Винничук, 2000; 2004; 2005; 2006; 2014).

Попри широке розповсюдження української готичної класики, поцінувачі „темної” літератури не мали можливості ознайомитися з її сучасними зразками. Щоправда, низка творів „вісімдесятників” i „дев'яностиків” (Монолог небіжчика Свгена Барана, Жінкозвір Марини Ломонос, Нотатки зниклого безвісти Сергія Герасимова, Годівля чорної собаки Андрія Дашкова та ін.), була поміщена у згаданій вище антології з 2000 року. Окрім того, протягом останніх двадцяти років з'являлися друком збірки „малої прози”, де можна було віднайти елементи сучасної літературної готики (Квіти в темній кімнаті, 1997; Книга екзотичних снів та реальних подій, 1999; Приватна колекиія: вибрана украӥнська проза та есеїстика кінця XX століття,

рівень аж ніяк не нижчий від рівня такого ж типу новел в літературах найрозвиненіших" (https://toloka.to/).

${ }^{2}$ Так назвав своє оповідання український письменник Михайло Могилянський (1873-1942). Згодом назву запозичив Валерій Шевчук (нар. 1938) - відомий письменник-шістдесятник і популяризатор готичних жанрів в українській літературі. 3 темних джерел життя - цикл наукових розвідок його авторства. (Шевчук, 1995). 
2002; Четверо за столом, 2004; Ця шокуюча Східна Європа, 2016 та ін.; див. Даниленко, 1997; 2016; Габор, 1999; 2002; Говда, Габор, Лишега, Портяк, 2004), але даремно шукати серед них найновіших зразків макабричного оповідання. Аж до 2016 року, коли вийшли протягом двох наступних років три збірки оповідань для прихильників вітчизняного горору й містики: Після опівночі (Дмитровський, 2016), Ігри з темрявою (Гаврильченко, Гранецька, 2016) $i$ Дотик зачаєного жаху (Михайлова, 2017). Усі три збірки оповідань вміщали твори фіналістів конкурсів, присвячених Стівену Кінгу (два перші) і Говарду Лавкрафту (третій). Конкурси жахів огранізували редактори літературно-художнього журналу online „Стос”.

I врешті, у травні 2019 року на полицях українських книгарень з'явилася збірка оповідань „Вбивство на вулиці... ”. На нашу думку, унікальна $з$ кількох причин. По-перше, тому, що згуртувала навколо себе справжніх любителів „темної” літератури - редакторів згадуваного вище журналу „Стос” та незалежного книжкового видавництва „Дім Химер”. По-друге, бо ж ці любителі організували перший в Україні конкурс макабричних оповідань, до того ж присвячений творчості Едгара А. По, що посприяло переосмисленню творчості американського письменника, розвиткові літератури жахів в українському письменстві і, головне, відкрило нові письменницькі імена. По-трете, тому що найкращі оповідання конкурсу були зібрані у згаданій збірці, що стала раритетом. Публікація посіла четверте місце в рейтингу продажів на Міжнародному фестивалі „Книжковий Арсенал” в Києві з 22 по 26 травня 2019, на якому цієї книги просто не вистачило всім охочим, а також увійшла у ТОП-5 продажів на Міжнародному книжковому фестивалі „Book Space”, що проходив з 21 по 23 червня цього ж року у Дніпрі. Ці рейтинги безумовно свідчать про успіх, укотре вже ламаючи стереотип, нібито „мала проза” менш яскрава у порівнянні з розлогими романними жанрами і нікому не цікава.

Книжка має цікаве візуальне оформлення. Обкладинка повністю відображає суть ідеї видання. У червоно-чорних кольорах, де, як відомо, червоний символізує кров, а чорний - смерть, поміщений портрет американського творця оповідань жахів - Едгара А. По, якому присвячено конкурс. Письменник - у вишиванці, начебто застерігає, що твори українських авторів - не епігонство, а творче переосмислення його 
художньої спадщини. „Вишенькою на торті” є мотив птахів, найімовірніше чорного ворона - як на обкладинці книжки, так і на кожній iї сторінці. Отож, кожен, хто придбає Вбивство на вулиці..., , матиме не лише цікавий матеріал до читання, але й прекрасно поліграфічно оформлену книжку.

Уже назва збірки - Вбивство на вулиці... (три крапки вказують на незавершеність думки), відсилає до онойменного оповідання американського письменника - Вбивства на вулиці Морг (1841), спонукаючи розгорнути іiі. Цікаво, що самі автори вважали своїм творчим натхненником не лише Едгара По, але й „письменників, що стояли біля витоків жанру, чиїми творами захоплюється не одне покоління поцінувачів жахливого” (Володимир Компанієць; див. Гаврильченко, 2019, 25), тобто Мері Шеллі, Брема Стокера, Філіпса Лавкрафта, Роберта Говарда, а також класиків літератури XX століття: Хорхе Луїса Борхеса, Франца Кафку, Тома Стоппарда (Максим Гах; див. Гаврильченко, 2019, 82).

Українське Вбивство на вулиці... вміщує сімнадцять найяскравіших зразків оповідань жахів, відібраних за конкурсом. Прикметно те, що редакторка журналу „Стос”, Аліса Гаврильченко не зраджує читачам, хто з авторів переможці конкурсу. Повідомляючи, що до збірки „ввійшли не лише твори переможців конкурсу, але й ті макабричні оповідання, що вразили суддів, проте поступилися більш сильним конкурентам" (Гаврильченко, 2019, 4), пропонує широке поле для інтерпретацій, уможливлює індивідуальне сприйняття окремих оповідань і вибір власних фаворитів.

Важко віднайти ключ, за яким укладачка визначила порядок розміщення творів у збірці. Зрозуміла зате черговість крайніх оповідань. Збірку відкриває оповідання Гілка глоду авторства Світлани Тараторіної, яка, як єдина авторка антології, сповістила в короткій довідці про свою перемогу в конкурсі. Детективний сюжет твору розповідає про Київ 1913 року, де одвічно змагаються два світи: людей і нечисті. Убивства на київських вулицях початку минулого століття намагається розслідувати слідчий Олександр Тюрин. Авторка звернулась до демонологічних основ, які властиві класичним оповіданням жахів в їх українській іпостасі. Про смаки не сперечаються, але, на мій погляд, оповідання переможниці не без творчих прорахунків. Незважаючи на 
„навальне” введення читача в дію, пор. „Я не пам’ятаю свого імені, не знаю, де перебуваю, і хто ця жінка, що конає на моїх руках" (Гаврильченко, 2019, 6), розповідь не тримає читача в напрузі однаковою мірою від початку до кінця, деякі фрагменти втомлюють, зокрема помітне перенасичення упирсько-відьомськими „реквізитами” (пор. „спеціальна камера для упирів”, „кайдани освячені на мощах святої Варвари”, „терен, часник, глід”, „спеціальна комісія з питань десмодусів”, „сильфіди - духи, на яких перетворилися дівчата, зраджені коханими”, „провідники повстань упирів” тощо).

Заключне оповідання збірки Заплановане вбивство: як усе починалося цікаве з двох причин. По-перше, воно авторства упорядниці збірки і редакторки журналу „Стос”, Аліси Гаврильченко, про що читач дізнається в анотації до книги, де пропонується йому „атмосферний прикінцевий бонус" (Гаврильченко, 2019, 2). По-друге, твір безпосередньо дотичний до творчості По. Він суголосний з його оповіданням Чорний кіт (1843), про що попереджає авторка, підкреслюючи, що iii твір слід сприймати „як своєрідний відгук на оповідання «Чорний кіт» По” (Гаврильченко, 2019, 250). Обидва оповідання єднає постать чорного кота-улюбленця, який впливає на життя героїв, вирішуючи свою і їхню долі. Твір захоплює атмосферою нез'ясованого жаху і зростаючої напруги, тим паче, що, повністю відсутні в ньому елементи „страшного” фольклору з усякими упирями, відьмами, потерчатами, бабаями тощо. Найбільш несподівана розв'язка - заголовне заплановане молодою героїнею вбивство обожнюваного батьком-егоцентриком кота Арея насправді виявляється запланованим вбивством цього ж батька. Злочин ще не скоєний, але читач добре розуміє, що рішення уже прийнято. Закінчення вражає, тим більше що розв'язка озвучена тільки в останньому реченні, пор. „Мій батько найбільше любить не матір, не мене... і навіть не тебе, рудий. I навіть не море. Найбільше він любить себе. Я не промовила вголос: «І тому вбити треба його»" (Гаврильченко, 2019, 254). Оповідання лаконічне, без зайвих описів, у стилі По, але й латиноамериканських „нефантастичних фантастів” Хуліо Кортасара чи Борхеса. А ще чимось нагадує „малу прозу” Василя Габора (1999) із збірки Книга екзотичних снів та реальних подій, про стиль якої свого часу влучно згадував письменник Володимир Кашка: „Вказати не називаючи. Зорієнтувати, не розповівши. Збудити 
тривогу в серці слухача і передпочування крику з пітьми, нічим того ж таки слухача-читача зримо не жахаючи" (Кашка, 2002, 152).

Сімнадцять відтінків страху, які пропонує відчути читачам укладачка сімнадцяти оповідань із збірки Вбивство на вулиці..., , кожне по-своєму цінне і може зацікавити читача. Увагу привертають інтригуючі заголовки, що мають символічне значення, але легко розшифровуються у ході розгортання подій. Гілка глоду (глід - оберіг від нечисті), Бабай (злий нічний дух), Живецьь (принада; життєва сила, енергія; Живець - капище Живи) чи Прикладна демонологія безпосередньо відсилають до глибоких фольклорних традицій і вказують на звертання їхніх авторів до джерел народної демонології. Птах у сухому гіллі (людська душа в мертвому тілі), Темніме за чорне (,дві зіниці, темніші за чорне" слідчого, до єства якого підселюється потойбічна „,істота в чорному плащі” і разом коять злочини) чи Секрет ї̈ чарівноcmi (секрет чарівності молодої жінки в їі демонському єстві - вона сукуб, що живиться життєвими силами своїх коханців, призводячи їх до смерті) та ін. - заголовки, що обіцяють таємницю з філософським забарвленням. Урешті, Вбивства в алфавітному місті чи Заплановане вбивство: як усе починалося - суголосні з назвою збірки і заголовком оповідання По і вказують на провідний для макабричних оповідань мотив душогубства.

Частина моторошних оповідань із збірки Вбивство на вулищі... продовжує чи не найпопулярніший у сучасній українській літературі мотив міста, яке відповідальне за відчуження людини, іiі виродження і смерть. Особливо гостро поставлене це питання у таких творах, як Вбивства в алфавітному місті, де протягом шести років установлено 33 жертви нерозгаданих убивств, що виявились своєрідними самогубствами („Не серійні вбивства, а серійні самогубства. Нас до цього тягнуло завжди. [...] іноді навіть купка розчавлених самогубців здатна залякати все місто. Якого ми не любили і боялися, яке не любило і боялося нас", Гаврильченко, 2019, 123), Збирач ненависті, в якому хворий раком корумпований слідчий уособлює сучасне місто і тому приречений на смерть заголовним збирачем ненависті ${ }^{3}$, чи,

${ }^{3}$ Пор. „Слідчий, який виборов свою кар’єру ціною страждань сотень людей. [...]. I ти скажеш мені, що міста не існують завдяки ненависті? Те, що змушує людину тікати 
врешті, Темніше за чорне, в якому місто як злочинне кодло стало ареною смертельного конфлікту між двома колишніми поліцейськими із втручанням потойбічних сил („Сутенери, наркоторговці, міліція, чиновники - все це було частиною одного механізму, який мав назву мегаполіс", Гаврильченко, 2019, 189).

У контексті останнього цілком зрозумілий вибір місця дії оповідань - це, головно, вулиці Києва (Гілка глоду, Збирач ненависті), Львова (Птах у сухому гіллі), Гніваня (Гніванським шосе вздовж провалля), Хижинців (Хижинський ярмарок), або інші неназвані міські простори України (Секрет ї̈ чарівності, Браслет, Плями, Темніше за чорне). Тільки дія одного оповідання збірки - Мілан Адаміч приносить користь розгортається поза межами України - у Відні.

Час дії більшості пропонованих у збірці творів - сучасність (Гніванським шосе вздовж провалля, Секрет ї̈ чарівності, Браслет, Збирач ненависті, Плями, Темніше за чорне, Хижинський ярмарок, Заплановане вбивство: як усе починалося та ін.), але є оповідання, які запрошують читача заглибитись у сповнене жахів минуле (Гілка глоду, Птах у сухому гіллі, Мілан Адаміч приносить користь, Живець).

У тих зразках макабричної „малої прози”, в яких оповідь ведеться від першої особи (Гілка глоду, Птах у сухому гіллі, Секрет ї̈ чарівності, Браслет, Живець, Плями, Прикладна демонологія, Заплановане вбивство: як усе починалося), посилене враження автентичності пережитого. Безпосередні учасники жахливих подій з найдетальнішими подробицями передають свої емоції, опиняючись у замкнутому колі страху. Цьому сприяє і застосований окремими авторами прийом навального введення читача в дію, який із перших рядків відчуває поспіль $з$ героями переляк. У цьому плані особливо цікаве оповідання Секрет ї̈ чарівності, яке починається і завершується ідентичними абзацами, що не дають ні героєві, ні читачеві жодної надії на щасливе закінчення моторошної історії, пор.:

Мені не судилося пережити цю ніч. Я усвідомив це, коли мені на плечі, руки, голову, один за одним опустилося з десяток нічних метеликів. Бурі волохаті комахи

від спокійного життя у самісіньку гущу міста - усі ті пороки - ось завдяки чого існують міста. А я збирач цих пороків. I ти будеш моїм головним обідом - переповненим ненавистю та болю” (Гаврильченко, 2019, 159). 
наче навмисне бруднили своєю мікроскопічною лускою моє чорне пальто, маркуючи приречену жертву. Я подивився на своє ліве плече, де розклав крила на диво великий метелик. 3 його ворсистого загривку на мене дивилася пляма у формі людського черепа. І ось тоді я злякався, найдужче у своєму вже майже скінченому житті (Гаврильченко, 2019, 55, 64).

Водночас, і класичні оповідання збірки, в яких розповідь ведеться від третьої особи, можуть не на жарт налякати читача, якого разом 3 оповідачем майже поглинає неподоланний страх. Показовим у цьому плані є перший епізод оповідання Бабай, в якому героїню, яка пізнім вечором повертається додому темною доріжкою, не покидає враження, що хтось за нею стежить. Наростаючий страх призводить іiі до отупіння на межі божевілля, пор.

Листя праворуч зашелестіло. Олеся на мить завмерла, прислухаючись: наче щось повзло... Ні, то просто вітер ворушив листям. Ось знову. Дівчина зупинилася і пильно вдивилася в темряву. Й одразу холодок пройшовся спиною: хтось дивився на неї звідти. Вона спробувала гукнути, крикнути, але тільки щось прошепотіла. [...] Зуби клацали від страху, тіло тремтіло. Олеся заклякла на місці, наче приросла до лавки, неспроможна встати, обернутися, навіть крикнути. [...] Олеся тихо скавчала. Слизькі пальці не втримали телефон, і той гепнувся об асфальт. Одразу настала темрява і тиша - наче світ помер. [...] М'язи задубіли від напруги, у грудях все скувало від холоду. Чорні пасма почали обгортати горло двічини... [...] Останньої фрази Олеся не розчула. Асфальт ударив їй в обличчя (Гаврильченко, 2019, 162-163).

Словом, усе залежить від уміння автора вселити в душу читача почуття тривоги й страху, створити напружену атмосферу жаху або болісного очікування чого-небудь жахливого. Останній прийом, що й в українському літературознавстві отримав англомовний термін cacneнс, властивий чи не всім оповіданням антології. А втім, твори із збірки Вбивство на вулиці... н не однакові за силою впливу на реципієнта. Глибоко у світ нез'ясованого жаху порине читач в оповіданнях, Птах у сухому гіллі, Гніванським шосе вздовж провалля, Секрет ї̈ чарівності, Живець, Бабай, Плями, Записка, Заплановане вбивство: як усе починалося.

Решта, попри свою безперечну вартість (адже всі вони пройшли конкурсний відбір), на мою думку, не без творчих недоглядів. Сюжети згадуваної вже Гілки глоду, Збирача ненависті, Пакистанки. Оповіді про втому чи Хижсиського ярмарку з приводу накопичення окремих 
деталей трохи розтягнені, через що не в кожному фрагменті розповіді тримають у напрузі, не завжди змушуючи тремтіти в очікуванні розв'язки. Це стосується й Птаха у сухому гіллі, сконструйованого на кшталт класичного оповідання жахів і в цілому дуже вдалого. Тільки прикінцеві роздуми героя ${ }^{4}$, враженого сумною історією приятеля, який заради смертельно хворої дружини вирішив знайти еліксір безсмертя і спровокував переродження коханої в кровожерне зомбі, за що поплатився життям, знімають ефект саспенсу, з яким кожен читач повинен розібратися індивідуально, відтак трохи послаблюють загальний ефект моторошності твору, який набуває філософсько-притчевого звучання.

Слід звернути увагу й на мовний аспект збірки Вбивство на вулиці..., оповідання якої написані гарною українською мовою. Стиль не перенасичений ні архаїзмами (зважмо, що деякі з письменників активно звернулись до демонологічних джерел українського фольклору), ні неологізмами чи іншомовною лексикою, властивими для сучасної міської прози. У текстах не використовується характерна для сьогоднішніх творців художнього слова ненормативна лексика. Загалом, книжка читається легко, з насолодою стилем, характерним для доброго детективу з готикою в тлі.

Ставлячи питання про причину і сенс постійної уваги читацької публіки до „темної” літератури і шукаючи на них відповіді, хочу згадати одну з рецензій на Легенди Львова (1999) Юрія Винничука, у назві якої прозвучав заклик „Розваж нас, налякай нас!” (Калинці, $1999,8)$. Автори рецензії захоплювались, між іншим, умінням „батька чорного гумору”, ентузіаста-упорядника відчизняної готичної спадщини, якого окремі твори зараховують до української готики і поміщають в антологіях жаху 5 , „заворожити читача фантастичними персонажами, що ними тішили й лякали [виділення курсивом - А.Г.-Ш.] свою увагу наші [українські - А.Г.-Ш.] пращури”, а також „провести

${ }^{4}$ Пор. „Чи будуть нащадки такими чутливими? Чи, може, вони ховатимуться за масками, як це роблю я? Співатимуть їхні душі одна для одної? Чи вони похмуро мовчатимуть посеред сухого гілля?” (Гаврильченко, 2019, 36)

${ }^{5}$ Оповідання Ю. Винничука Ги-Ги-Ги та Ласкаво просимо в Щуроград увійшли в Антологію украӥнського жаху (Пахаренко, 2000), День ангела - в антологію Чорт зна щุo (Винничук, 2004). 
паралель чи порівняння із сучасністю, заакцнетувавши на моральних цінностях героїв” (Калинці, 1999, 8).

Такий самий задум видавців й авторів Вбивства на вулиці .... налякати читача, щоб його розважити, і водночас наголосити на злободенних проблемах сучасної людини, життя якій укорочують злість, заздрощі, хтивість, пиха, на що, між іншим, звернула увагу у передмові Аліса Гаврильченко. На їі думку, книга

як колись раб у Стародавньому Римі за спиною воєначальника, тихо нагадує: «Memento mori» («Пам’ятай про смерть!»). А може, насправді фраза звучала так: «Respice eshkere post te! Hominem te memento!» («Озирнися! Пам’ятай, що ти людина!»). Якщо це так, тоді цінність збірки тільки збільшується, бо загалом книга нагадує, що ти насамперед людина, і кожен твір у збірці містить певну мораль. Саме цим і сильні горор та детектив - у цих жанрах завжди є мораль. У детективі рано чи пізно перемагає справедливість. У горорі рано чи пізно жах карає винного, дурного або необережного (Гаврильченко, 2019, 5).

Влучно вказав також на назрілі для письменицької, утім готичної, творчості мотиви Олег Корнійчук, автор оповідання Прикладна демонологія: „Занепад імперії, крах богів, злам парадигм, сходження і падіння тиранів, війна за свободу і відчайдушне, самовіддане протистояння злу" (Гаврильченко, 2019, 239). А, отже, при перегляді Вбивства на вулиці... хочеться, парафразувавши цитовані вище слова рецензії, окликнути: „Розваж нас, налякай нас, застережи нас!”.

I ще прикінцева заувага, що на цей раз стосується жанрової класифікації поміщених у збірці творів. Намагаючись визначитись із жанровою специфікою оповідань, ініціатори видання, рецензенти книжки вжили термін „химерний”, „химерна проза” (пор. „мета проекту - видання книг українських письменників, котрі спеціалізуються на химерній жанровій та авторській прозі” (Гаврильченко, 2019, 5); „сімнадцять химерних історій” (Юліна, 2019). Маючи свідомість умовності терміна „химерний”, мусимо однак заперечити обгрунтованість його використання у контексті макабричних оповідань. Термін „химерний роман” з легкої руки Олександра Ільченка прижився в українській літературі з приводу його роману Козацькому роду нема переводу, або Мамай $і$ Чужа Молодиия (1958), а точніше - підзаголовка „Український химерний роман з народних уст”, який поклав початок якісно новому етапові в розвитку вітчизняної романістики 
- „химерному” роману. Останній став феноменом в українському письменстві 70-х і 80-х років XX ст. і торкався таких відомих імен, як Василь Земляк (Лебедина зграя, 1971; Зелені млини, 1976), Володимир Дрозд (Ирій, 1974), Віктор Міняйло (Зорі та оселедизі, 1972; На ясні зорі, 1975), Свген Гуцало (Позичений чоловік; Приватне життя феномена; Парад планет; 1982-1984 ), Валерій Шевчук (Дім на горі, 1983) та ін. „Химерний” роман з його стильовою розкутістю, прийомами нежиттєподібності, письменницьким експериментаторством тощо став відповіддю на неможливість у перехідних 80-х і зокрема застійних 70-х роках минулого століття, в умовах несвободи донести до читача вагоме слово, повернутись до історичних і фольклорних джерел, подолати закостенілі приписи соцреалізму (Horniatko-Szumiłowicz, 2011). Для макабричних оповідань можна відшукати більш удалі визначення, зокрема оповідання жахів, моторошна „мала проза", горор-оповідання, готичні оповідання тощо, як, до речі пропонують цитовані вище видавці, пор.

Що ми розуміємо під назвою «Химерна проза»? Власне, увесь той пласт «темної» літератури, що його наразі складають містично-психологічні трилери, горор, детективний нуар, соціальна фантастика, неоготика, темне фентезі, стім-панк, романи й оповідання на основі історичних містифікацій, екзистенційний (пост) апокаліпсис, футуристична (анти)утопія тощо (Гаврильченко, 2019, 259).

Зрештою, і самі автори збірки влучно характеризували жанрову своєрідність власних оповідань з елементами „детективу, нуару, готики і чогось відверто абсурдного" (Ілля Лоскучерявий; Гаврильченко, 2019, 206), запрошуючи шанувальників „ретродетективу, вірду, круто змішаного на архаїчній міфології, карколомних пригод у найнеймовірніших локаціях” (Віталій Геник; див. Гаврильченко, 2019, 125) тощо.

Оповідання зі збірки Вбивство на вулиці... дуже різні, попри їхню спільну мету - завести читача у найтемніші завулки страху, з використанням творчого досвіду По - беззаперечного авторитету в галузі моторошної літератури. Незважаючи на їі унікальність вона припаде 
до душі далеко не всім. У першу чергу з приводу накопичення макабричних подій і обставин, жахливих убивств, безпросвітного у своїй суті попередження memento mori!, яке супроводить героїв усіх оповідань збірки.

Мені вона сподобалася з самого початку: 3 оригінальної обкладинки, інтригуючої анотації і заохочуючої передмови, знакових заголовків, вільної форми авторських довідок, розміщених перед текстом оповідань, урешті, змісту оповідань, кожне з яких по-своєму моторошне. Словом, попри вказані раніше прорахунки, для мене - це справжній раритет. Так само, думаю, для поцінувачів літературного жаху, які завжди готові на „герць зі страхом” (Василь Пахаренко; Пахаренко, 2000, 791). Чи заслуговуватиме мала антологія звання сучасного варіанта „найстрашнішої книги в історії України” (Наталія Заболотна; Пахаренко, 2000, 3) - покаже час. А наразі рекомендую книжку усім, щоб, попри літературні смаки, скуштували, за влучним висловом одного з авторів, „ложку страху в діжці мотороші” (Гаврильченко, 2019, 125). Думаю, і тим, хто з прискореним серцебиттям стежить за кожною новинкою „темної” літератури, досліджуючи їі особливості, 3 гордістю стверджуючи тяглість розвитку української готики, і тим, хто знехотя сягне книжку з полиці і погортає, щоб побороти нудьгу чи просто заради хвилинної примхи, буде цікаво й корисно iï прочитати.

\section{Література}

Винничук, Ю. (упоряд.) (1990). Огненний змій. Фантастичні твори украӥнських письменників XIX сторіччя. Передм. В. Шевчук. Київ: Молодь.

Винничук, Ю. (ред.) (2001). Нічний гість. Збірка оповідань. Львів: Піраміда.

Винничук, Ю. (упоряд., ред., перекл.) (2004), Чорт зна що. Львів: Піраміда.

Винничук, Ю. (упоряд.) (2005). Потойбічне. Українська тотична проза XX cm. Вступне слово, біограф. відомості Ю. Винничук. Львів: Піраміда.

Винничук, Ю. (упоряд.) (2006). Огняний змій. Украӥнська тотична проза XIX cm. Біограф. відомості, ред. текстів та перекл. Ю. Винничук. Львів: Піраміда.

Винничук, Ю. (упоряд.) (2014). Антологія украӥнської тотичної прози. У двох томах. Харків: Фоліо.

Габор, В. (1999). Книга екзотичних снів та реальних подій. Львів: Класика.

Габор, В. (упоряд.) (2002). Приватна колекція: вибрана украӥнська проза та есеӥстика кіния XX століття. Львів: Піраміда. 
Гаврильченко, А. (укл. і передм.) (2019). Вбивство на вулиці... Збірка оповідань. Вінниця: Дім Химер.

Гаврильченко, А., Гранецька, В. (ред.-упоряд.) (2016). Ігри з темрявою. Збірка horror-оповідань. Серія „Позапростір”, вип. 5. Луцьк: ПВД „Твердиня”.

Говда, О., Габор, В., Лишега, О., Портяк, В. (2004). ,Четверо за столом”: Антологія чотирьох приятелів. Львів: Піраміда.

Даниленко, В. (упоряд.) (1997). Квіти в темній кімнаті. Сучасна українська новела. Київ: Генеза.

Данилнеко, В. (упоряд.) (2016). Ця шокуюча Східна Європа. Антологія українського оповідання XXI століття (2000-2015). Київ: Фенікс.

Дмитровський, О. (упоряд.) (2016). Після опівночі. Збірка оповідань. Вступ О. Бондаренко. Вінниця: Айс Принт.

Калинці. (1999). Розваж нас, налякай нас!, „Поступ” ч. 108, с. 8.

Кашка, В. (2002). Наздогнати черепаху. 3 приводу прози Василя Габора. „Дзвін” № 4, c. $148-156$.

Михайлова, В. (ред-упоряд.) (2017). Дотик зачаєного жаху. Збірка малої horror-nрози. Київ: Електрокнига.

Пахаренко В. (упоряд.) (2000.) Антологія українського жсаху. Київ: Асоціація підтримки української популярної літератури.

Шевчук, В. (1995). 3 темних джерел життя. Українська готична новела ХХ століття. „Літературна Україна” № 4, 5, 6 .

Юліна, Ю. (2019). Сімнадиять химерних історій. http://stos.com.ua/2019/07/05/ сімнадцять-химерних-історій/\#more-6040. 5.07.2019.

Horniatko-Szumiłowicz, A. (2011). Ukraińska proza „chimeryczna” lat siedemdziesiatych i osiemdziesiatych XX wieku. Geneza, rozwój, konteksty literackie. Szczecin: Wydawnictwo Naukowe Uniwersytetu Szczecińskiego. 